\title{
K. H. Ting's Contribution to the Contextualization of Christianity in China
}

\section{Ruokanen, Miikka}

2009

Ruokanen, M 2009 , ' K. H. Ting's Contribution to the Contextualization of Christianity in China ', Modern Theology , vol. 25 , no. 1 , pp. 107-122 . https://doi.org/10.1111/j.1468-0025.2008.01503.x

http://hdl.handle.net/10138/314414

https://doi.org/10.1111/j.1468-0025.2008.01503.x

acceptedVersion

Downloaded from Helda, University of Helsinki institutional repository.

This is an electronic reprint of the original article.

This reprint may differ from the original in pagination and typographic detail.

Please cite the original version. 


\section{K. H. TING'S CONTRIBUTION TO THE CONTEXTUALIZATION OF CHRISTIANITY IN CHINA}

\section{MIIKKA RUOKANEN}

Communist ideology has for half a century done its best to eradicate the influence of traditional Chinese beliefs and morality in China. Now Communism itself has lost its credibility as an ideological system and has become purely a pragmatic tool for ruling the vast multicultural country. Hundreds of millions of Chinese are looking for a new orientation as they seek to understand the value and meaning of their lives and to build up their moral worldview.

All the religions of China at the present time are growing, to some extent filling the vacuum of faith and values. Protestant Christianity is the fastest growing religion of them all. According to Chinese scholars of religion, some two million adults receive baptism each year, one million in the registered churches under the guidance of the Three-Self Patriotic Movement and the China Christian Council, another million among the non-registered groups. China is possibly witnessing the fastest church growth in history. ${ }^{1}$

Bishop K. H. Ting (Ding Guangxun, b. 1915) has been since the 1950s the leading figure of both the Chinese Protestant church and of Chinese theological thinking. His role as the most outstanding representative of Chinese Protestant Christianity from the early 1950s to the present is incomparable in the history of nearly any church of our times. He has held all the top posts of the Chinese Protestant church and has an important role in the Chinese national political establishment. ${ }^{2}$

Miikka Ruokanen

Faculty of Theology, Box 33, 00014 University of Helsinki

FINLAND miikka.ruokanen@helsinki.fi; He is also Guest Professor in the Renmin (People's) University of China (Beijing), Advisory Professor in the Fudan University (Shanghai), and Visiting Professor in the Nanjing Union Theological Seminary (Nanjing). 
The present review essay is mainly based on a close, systematic-analytical reading of Ting's recently published 624-page magnum opus God is Love: Collected Writings of Bishop K. H. Ting (Colorado Springs, CO: Cook Communications, 2004). This work is a collection of his theological essays and speeches spanning various decades, but it also includes new, previously unpublished essays. The essay at hand intends to systematize those thoughts which are not given in a systematic form in his most important book. ${ }^{3}$ The 87 essays are divided into five main sections which have, from the systematic or historical point of view, somewhat ambiguous titles. ${ }^{4}$ It might have been better had the essays been arranged in a chronological order. They cover a period of about sixty years, from the 1940s to the 2000s; the 1980s seem to have been the most productive period of Ting's theological writing.

\section{The Defender of the Faith}

Bishop Ting has been working for half a century under enormously challenging and demanding conditions. His major work, God is Love, demonstrates the practical wisdom of a skillful church leader and a widely-read theological writer. His opus offers us a vivid and many-sided picture of his unique career as a church leader and as a theological writer and essayist in modern China.

The article "The Church and China's New Constitution" (1983, pp. 544$547)^{5}$ illustrates how Ting, as a member of the Commission for Constitutional Revision of the National People's Congress, took part in the process of drafting the new constitution of China after the so-called Cultural Revolution. He had at that time a particular opportunity to defend the policy of religious freedom and to contribute to the protection of the legal rights of religious believers. Ting's article "The Church and State" (1984, pp. 562-575) further accentuates and clarifies his commitment to defending the rights of religious believers in a socialist society.

K. H. Ting reflects the specific nature of the Chinese church over against the long history of the Christian church, giving counsel to Christians living in a socialist society: "For almost 2,000 years the Christian church has co-existed with all sorts of non-Christians and atheists and found common ground with them. There is no cause for alarm and panic" (1987, p. 560).

Modern theology would affirm that there is no ideal model of a "Christian society" despite the fact that many churches have throughout history fallen into this fallacy. Society is always secular, and the church should cooperate with it, being the prophetic light and the salt of righteousness which fosters social justice, paying special attention to those who are the weakest members of the society. The basis of cooperation between the secular and ecclesiastical orders is the natural moral law, engraved on every human conscience by the Creator. ${ }^{6}$ 
Those Chinese Christians who for whatever reason do not understand or appreciate K. H. Ting's work have no doubt nevertheless benefited from his role as the protector of the church and as the defender of the faith, struggling for the legal rights of Christians to worship and to practice their faith. The reader of God is Love can only imagine what great effort, behind the scenes, invisible to the public eye, the writer must have expended in his long career to defend the legitimacy of religious belief in China.

$\mathrm{K}$. H. Ting's contribution as the defender of the faith has also an academic dimension. Following the long tradition of the apologists of the Christian church, he uses the authoritative texts of his discussion partners-in this case the Marxists-to demonstrate that their own theoretical authorities, both European and Chinese, indeed allow the legitimacy of religious faith. Ting persuades his opponents to admit that faith in God is both rationally meaningful and morally beneficial. His article "Is Religion an Opiate?" (1985, pp. 515-526) is an illuminating example of this kind of apology. So is the article "Religion and Socialism: Can They Co-exist?" (1989, pp. 526-543; co-authored with Wang Weifan). Ting's interest in the defense of the faith is a persistent feature in his theological thinking; the article "On Christian Theism" (1957, pp. 91-108) is an example of apology from his early career.

\section{The Problem}

K. H. Ting launched in 1998 a program for the "Reconstruction of Theological Thinking" in China. On the one hand, the background of this theological movement lies in the policy of the Chinese government to encourage religions "to play an active role in promoting social harmony." On the other hand, after twenty years of the rapid development of church life since the opening up of China in the late 1970's, there was a growing need for "developing theological thought to function in guiding the church construction." Successful church growth needed theological reflection. A "Resolution on Strengthening Theological Reconstruction," approved by a special theological conference held in Jinan, Shandong Province, in November 1998, stated: "Even more, the deepening and opening up of self-propagation demands lively theological reflection and exploration of how to better spread the Gospel; how to guide Christians in their spiritual and in their daily lives; how to promote Christian ethics and morality; how to glorify God and benefit the people." ${ }^{7}$

There are many critical voices within and outside China claiming that, when initiating the movement for the "Reconstruction of Theological Thinking," Ting's aims were merely political: he intended to "neutralize" Christianity by making it follow too closely the agenda of the Communist Party of China. According to the critics, certain essential areas of Christian doctrine, such as Christology and the doctrine of justification by faith, are distorted in a process of "harmonization" between Christian and non-Christian understandings; 
religious faith is in the end replaced by morality. One of the main critics of Ting for three decades was the late Jonathan Chao, who viewed Ting as "an unreconstructed liberal who was promoting theological reconstruction as the agenda of the Chinese Communist Party." ${ }^{8}$

Another critic of K. H. Ting, Liu Yichun, contends that modern Protestant theology in China is "compromising unconditionally with the mainstream ideology, cooperating with political need." According to Liu, Protestant leaders "have destroyed the Chinese church in the name of loving the church. ${ }^{\prime \prime}$ Li Xinyuan, who also criticizes Ting, says that Ting's emphasis on God as love and his "cosmic Christology" are expressions of a liberal universalism that intends to obscure the distinct identity of Christians. By "downplaying" the emphasis of the justification of the sinner by grace through faith alone, the differences between believers and non-believers are softened in the name of social harmony. This kind of theology, Li believes, "changes the Gospel and confuses the truth."10

Most often the critics of K. H. Ting view his idea of "the cosmic Christ" as a step toward building a bridge between the church and Chinese socialist realities, opening up a way to collaboration with atheistic Communists. Ting sees the realm of God extending beyond the narrow circle of believers; all who put love into practice are God's coworkers, without even being conscious of it. ${ }^{11}$ This kind of theological reasoning sounds strange to most Chinese believers; therefore, "there will be critics who will question whether Ting's theology is anything more than an exercise in convenient adaptation to a politically sensitive context."12

My intention here is to show that much of the criticism of K. H. Ting is based on an insufficient understanding of his theological thinking. I will therefore attempt to illuminate his authentic intentions for the development and contextualization of Protestant Christianity in modern China.

\section{Introducing A Wider Scope of Theology for Chinese Protestants}

The spirituality of most Chinese Protestant believers and pastors is rooted in the profoundly conservative views of the Evangelical-revivalist and Pietistic missionaries who brought Protestant Christianity to China. Emphasis is on the salvation of the individual. The view of this world is negative: salvation means being wrenched off this evil world. ${ }^{13}$ In his theological work, K. H. Ting intends to broaden the narrow and to a certain extent escapist theological scope of Chinese believers in the direction of classical and modern theology, both mainline Protestant and Catholic.

As Philip Wickeri points out, K. H. Ting's theological thinking is deeply rooted in the liberal and catholic Anglican theology of the 1930s and 1940s which was prevailing at St. John's School of Theology in Shanghai where Ting received his initial theological training. There was an emphasis on the Incarnation, the Trinity, the connection between creation and redemption, the 
striving after synthesis between theology and contemporary culture, a historical-critical approach to the Bible, and, most importantly, love as God's major attribute. According to Wickeri, Ting always remained remarkably consistent. In the 1980s, during the most productive period of his writing, he was concentrating on similar themes, such as "the love of God in Christ, the work of the Holy Spirit both inside and outside the church, the interrelatedness of creation and redemption, the importance of ethics, and human cooperation with God in historical movements for change." ${ }^{\prime 14}$

Anglican theology did not have interest in creating a church dogmatics or writing compendiums of systematic theology. Neither was it ever so much concerned about the doctrine of justification as the Lutherans and the Calvinists always were. Those criticizing Ting for "downplaying" the doctrine of justification should pay attention to Ting's overall theological scope before linking his intentions with political agendas. Due to his background in liberal Anglican theology, Ting always felt some "uneasiness" about the emphasis on the doctrine of justification by faith. ${ }^{15}$

What Ting in fact is doing is introducing into the Chinese Christian milieu some theological concepts and ideas which are widely accepted as legitimate ecumenical expressions of the Christian faith in the West; but these notions are new in the conservative context of Chinese Protestantism. In so doing, Ting attempts to create a basis for a meaningful dialogue between the church and the socialist society (though it is perhaps better to say, the so-called "socialist" society, as China has in fact become a totalitarian one-party capitalist society), between Christianity and Chinese culture, and between the Christians and the non-believers or those who maintain other faiths. He aims at helping Chinese Christians cope better with their distinctive social, political, and cultural context. This is something that the most conservative Chinese Christians find difficult to understand or accept.

K. H. Ting's theological ideas are common in a great part of Western theology, but they are in many ways in tension with the conservative revivalist and Evangelical ethos of Chinese Protestantism. Moreover, his theological intentions were often understood as linked with a political agenda, which caused suspicion among the believers. Philip Wickeri sums up: "None of Ting's ideas were very radical when viewed from the perspective of contextual theological writing in other parts of the world over the last fifty years. They became controversial in China because Ting was challenging fundamentalism directly, and because many Chinese Christians saw his theology as part of a broader political initiative that was being imposed on them from above."16

\section{Concentration on the Method of Theology}

In God is Love Bishop Ting does not aim at offering a systematic presentation of his understanding of the entire content of the Christian faith. Rather, Ting develops in his essays and speeches certain methodological approaches and 
rules which he supposes to be necessary for creating an authentically Chinese adaptation and understanding of the Christian Gospel. Ting seems to set forth certain basic principles upon which a uniquely Chinese theology might be developed; he leaves younger theologians the actual work of creating and writing such theologies.

I find in Ting's writings basically two methodological principles which he employs in order to renew and expand the traditionally rather narrow, individualistic salvational orientation in Chinese Protestantism to a larger view of how God relates himself to his creation. First, Ting's understanding of God as love is based on a strong Trinitarian theology, which provides a platform for viewing the whole creation as something that is good, i.e., as the sphere of the presence and action of the Holy Trinity, of "God who is love." A Trinitarian approach to theology leads into a holistic view of God and the world; there are many ways in which the Trinitarian God takes up relation with his creation and with humanity.

Second, in the light of the universality of the activity of the Holy Trinity, an activity of larger scope than God's work in the church, Ting emphasizes natural theology, which includes both the recognition of certain divine truths in the context of nature and in the reality of natural moral law. These are the main methodological premises on the basis of which $\mathrm{K}$. H. Ting seeks to create a contextually relevant theology in the situation of modern Chinese Protestantism.

\section{The Trinitarian Structure of Theology}

Having given consideration to the first aspect, we can see how K. H. Ting explicates a clearly Trinitarian theology: as the Holy Trinity, God himself is the community of love who desires to include his creation, especially humanity, in the communion of love which he himself is. "The very Trinity tells us that God Himself is a community of love." (See, for instance, 1984, p. 68; 1984, p. 283.)

Ting combines the themes of reconciliation and consummation with that of creation: it is the very work of Christ and of the Holy Spirit to accomplish God's original plan of creation, to create a deep union or communion between humanity and the Triune God. "Humanity has appeared, but the community is not yet accomplished. Contradictions still erupt among people. What will bring this stage to an end? The realization of community. This is the sanctifying work of the Holy Spirit, the saving work of Jesus Christ, and the creative work of God." Conceiving of creation as a continuing process of God's redemptive and sanctifying work, Ting is attracted to the concept of the human being as "a half-finished product of past creation" which continually stands in need of "further transformation" (1985, p. 301).

Referring to the French Catholic theologian Pierre Teilhard de Chardin, Ting states: "The community of the Father, Son, and Holy Spirit is not enough. It must be enlarged to enable all humanity to enter. In Teilhard's words, 'God 
is not will-to-power but will-to-fellowship'" (1985, p. 297). Ting here underlines in a significant way that love is not just one attribute of God among others, but that it is the true essence of the Triune God (1984, p. 60). Ting at this point follows the mainstream of Augustinian Trinitarian theology. He also echoes the contemporary Catholic teaching on Trinitarian theology. The Catechism of the Catholic Church (1992) teaches: "God's very being is love. ... God himself is an eternal exchange of love, Father, Son and the Holy Spirit, and he has destined us to share in that exchange." "The ultimate end of the whole divine economy is the entry of God's creatures into the perfect unity of the Blessed Trinity."17

The author of God is Love is developing a Trinitarian approach to theology at the same time that a similar Trinitarian revival began to take place in Western Catholic and Protestant systematic theologies. Karl Rahner and Henri de Lubac have followers in most recent Catholic theology who emphasize the Trinitarian approach and understand God as love. The normative Catechism of the Catholic Church, which develops the legacy of the Second Vatican Council, is thoroughly Trinitarian.

In respect to Protestantism, it was Karl Barth who was deeply aware of the need of developing theology on a Trinitarian basis; he himself, however, did not get very far in this approach. But more recent, ecumenically-oriented and influential mainline Protestant theologians have been schooled within and shaped by the Trinitarian revival of systematic theology emphasizing God's essence as love: W. Pannenberg, J. Moltmann, E. Jüngel, T. F. Torrance, R. W. Jenson, C. Gunton, S. J. Grenz, et alia. But it seems that K. H. Ting has arrived at this conclusion more or less independently of, though at the same time as, the Trinitarian developments in the West. Most likely, his background in the Anglican theology of the 1930s and 1940s contributed to the Trinitarian orientation of his theology.

Clearly visible in God is Love is that a Trinitarian approach to theology leads into a holistic view of God and world. All three persons of the Holy Trinity are active at the same time: in creation, in redemption, and in sanctification. This recalls the classical principle of the early Church Fathers: "The works of the Holy Trinity outside himself are indivisible" (opera Trinatis ad extra sunt indivisa).

The influence of God's grace is greater than the influence of the Christian church, because all three persons of the Trinity are active already in creation. Consequently, there are many ways in which the Trinitarian God can be related to his creation and to humanity even outside the church; and this notion leads K. H. Ting to employ the concept of the cosmic Christ. The cosmic Christ "is the co-creator working with God in the process of creation, the revealer of God's love, the Risen Lord who sustains all things by his word of power" (1992, p. 132).

Above all, Ting seems to use the concept of the cosmic Christ to emphasize the active participation of the Second Person of the Trinity in creation, thus 
establishing the possibility that even non-Christians might have some kind of relationship with Christ on the basis of creation alone (his favorite Biblical references in this regard are John 1, Colossians 1, Hebrews 1, etc.). In this sense, cosmic Christology both expresses Ting's broad theological conceptuality and serves the social-ethical end of offering a theological foundation for the harmonious coexistence between Christians and non-Christians. ${ }^{18}$

In addition to the new vision of cosmic Christology, the Trinitarian nature of K. H. Ting's theology appears also in his emphasis on the work of the Third Person of the Holy Trinity, the Holy Spirit. The work of the Holy Spirit is not limited to the reality of the Christian church, for, being the Spirit of creation (Spiritus Creator), he is active in all the world and in all history. Ting likes to employ expressions such as "the Holy Spirit's work of inspiration and sanctification in the world" or "the Holy Spirit inspires wisdom in all people" (1990, p. 433; 1989, p. 513). ${ }^{19}$

The Trinitarian understanding of God as love leads Ting to expand the scope of theology from soteriology to an emphasis on the theology of creation, theological anthropology, theological ethics, etc., all seen in the Trinitarian context. In Western theology, all of these topics are viewed as substantial parts of any ecumenically-oriented systematic theology. But in Chinese conservative Protestant theology and spirituality, inherited from the Evangelicalism and Pietism of the previous missionaries, these themes appear quite new and, consequently, have also been criticized by many.

\section{Introducing Natural Theology}

The second aspect of K. H. Ting's theological method aims at developing a certain kind of natural theology, which is underemphasized or even nonexistent in the Evangelical-Pietistic theological tradition of Chinese Christianity. Natural theology is for the most part a weak point in conservative Protestant theology everywhere in the world, whereas it is an essential part of Catholic and most mainline Protestant theologies.

Following this tradition, Ting emphasizes that Christians should recognize moral goodness, wisdom, and beauty outside Christianity and the Christian church. Ting also intends to overcome the overly simple dualism that divides Christian reality into the realm of Satan and the realm of actual salvation, posing no possibility of natural goodness between them. According to him, this world is, after all, created by a good God for a good purpose. Consequently, we should see the goodness of this world in spite of the fact of sin and evil, which, to a certain extent, distort and obscure the goodness of creation.

Following both contemporary mainline Protestant and Catholic teaching, Ting can affirm that, on the basis of general or natural revelation of God, the knowledge of divine truth, such as the existence of one God and of various of his qualities, can to some extent be grasped outside the Christian message. 
He sums up: "We have no reason to be afraid of truth that comes from sources other than Christianity. There is no truth but truth" $\left(1979\right.$, p. 176). ${ }^{20}$

According to mainstream theological thinking, non-Christians as well as Christians possess a conscience created by God; thus, they grasp a natural moral law which is, in fact, the same as the moral teaching of the Bible: the Ten Commandments, the Golden Rule, the Double Commandment of Love, etc. The problem of freedom arises, of course, in that we must ask whether people have the capacity to do what is right or to refrain from doing what they know is wrong. But this problem pertains to non-Christians as well as to Christians, as we learn from Paul (see Romans 7). K. H. Ting's emphasis on natural theology helps Christians to appreciate religious and moral truth as comprehensible as well among non-Christians, making possible a constructive religious and cultural dialogue and cooperation in matters of ethics and social justice.

That K. H. Ting pays attention to a natural theology which is profoundly underestimated in Chinese Christian theology and spirituality is an important reason why ethics and morality have a prominent place his system of thought. Some critics, however, claim that his theology fails to take into proper account certain essential aspects of traditional theology. Against such criticism we can say that, while Ting has the tendency to emphasize those new elements of theology that are weak in Chinese Protestantism, this does not mean that he is lacking the other, more traditional elements of revelational theology. They still remain a substantial part of his thinking, a subject to which I now turn.

\section{On the Foundation of Classical Dogma}

In his major work God is Love Bishop K. H. Ting tells what he has learned from recent theological schools of thought outside China (see, for instance, his article "Modern Theologies," 1985, pp. 287-314). He evaluates three schools of thought: Third World Liberation Theology, Teilhard de Chardin's evolutional theology, and American Process Theology. Certainly, the Western philosophical Idealism underlying both Teilhard's theology and Process Theology has some influence on Ting's theology.

But Ting can also draw from his own cultural sources: the traditional Chinese view of the human being is optimistic. In the history of Christianity, schools of theology vary in understanding the degree of the goodness and the sinfulness of the human race. Traditionally, some Protestants emphasize the total depravity of the human being, whereas some Catholics take the view that sin only slightly violates the natural goodness of humanity.

K. H. Ting himself notes certain limits to what he can learn from the above-mentioned schools of theology. For instance, he says that Teilhard, after all, is "a product of French culture and French higher education." His cultural limitations are expressed in his Euro-centrism: "He feels that the 
Orient has little of value to offer to the whole of humankind. His Orient is 'in a state of inertia'" (1985, p. 305). We can understand that Ting adopts methodological principles from Teilhard (Trinitarian love, cosmic Christ, ongoing creation, etc.), but he wishes to find authentically Asian and Chinese ways of expressing the proper content of these beliefs. Such a new Oriental contextual understanding of Christianity could be a great contribution to the global process of a deeper understanding of the whole significance of Christ.

During the last 150 years many of the Western liberal theologians have given up the classical foundation of the Christian faith expressed in the ancient creeds. In the name of rationality and the necessity of "demythologization," many made Christianity an ideology, an ethical program, or a projection of the human experience of our existence in the world.

But K. H. Ting does not fall into this trap. First, he understands philosophically the true nature of religion as being more than mere ethics or humanism: religion is about the "ultimate questions" or "high-level questions" which can never be satisfactorily solved by science or ethics alone (see the two articles: "The Fragrance of the Gospel," 1985, pp. 360-367 and "Jesus Brings Good News," 1985, pp. 367-372). Here Ting is in full agreement with modern philosophy of religion, understanding religion as attempting in its own right to answer the ultimate questions which cannot be answered by any other means: What is the meaning of life? What is true happiness? Why do we exist? What is the origin and final destiny of the universe and humanity? How are we to understand the riddle of death? etc.

Second, from a theological perspective, Ting sees reconciliation between God and humanity as the main content of theology: "Reconciliation between God and humanity is the eternal theme of Christian theology" (1985, p. 294; see also 1988, pp. 22-23). He also contends: "Jesus Christ is the center of Christian faith. People need to know him. It is our church's primary duty to help people to know him" (1989, p. 511). He emphasizes that "our basic faith should remain untouched" (2001, p. 449). Furthermore, he affirms the Apostles' Creed and the Nicene Creed as the true and binding expressions of the Christian faith and at the same time sees here a major theological task: "I do affirm my faith with all Christians as formulated in the Apostles' Creed and Nicene Creed, although I admit my inadequacy to explain the creeds well. I recognize them as two good ways to summarize the essential content of the Christian faith. To apply them in a Chinese context is a real challenge to us" (2004, p. 621). God's revelation does not change, but our understanding of it in different social, cultural, and historical contexts varies.

Bishop Ting explicitly emphasizes the classical foundation of Christian theology; Christianity cannot be reduced to morality, but a strong morality can be based on the foundation of Christianity: "I do believe that Christianity should lift up morality. But this is in no way to suggest that Christianity is concerned only with ethics and morality and even less to suggest that Christian faith be replaced with either.... The core of Christianity is faith and 
doctrine. Christian faith and doctrine are contained in the Apostles' Creed and the Nicene Creed, both ancient creeds." In saying this, however, Ting again underlines the necessity of the contextual understanding of the classical creeds: "Ethical and moral concepts change slowly, moving with the times. Neither is theology the same as faith and doctrine; rather, both ethics and theology explain faith and doctrine and inevitably change according to people, time, and place. There is only one Christianity, but there are many and various theological views within Christianity" (1999, p. 458).

\section{Towards a Chinese Contextual Theology}

In modern global theological discourse it has become commonplace to emphasize the need for the contextualization or inculturation of the Christian Gospel into various social, cultural, and historical contexts. At certain points in the past, Western theology was seen as some kind of "pure" or normative form of Christian theology. But during the last thirty years or so the global theological scene has changed drastically in this respect.

Roughly speaking, the term "contextualization" is composed of two main dimensions: first, understanding the Gospel in the context of modern social, political, and historical realities, and second, relating the message of the Gospel to the authentic cultural elements and experiences of a certain nation (inculturation). Of course, in our modern "global village" these two dimensions are not clear-cut, but are often in complicated ways mixed with each other.

I take the view that Bishop Ting's theological methodology is a very welljustified endeavor to find ways of expressing the Gospel of Jesus Christ in relevant ways to the Chinese of today's China. His methodology contains elements of both dimensions of contextualization, but he emphasizes the social, political, and historical dimension. And because he does, it comes as no surprise that he emphasizes as well in his thinking the ethical dimension of Christianity.

There is an important issue concerning how Ting relates the social, political, and historical aspects of contextualization of the practices of the modern socialist society in China to the Christian message. For Chinese society is becoming more and more dominated by market economy ideology and values. This "socialist" society is in fact a mixture of many different kinds of influences and elements. In addition to the socialist education, there are in the mind of the Chinese, remnants of the traditional Chinese worldview and its values, and all of these are mixed with a multitude of new ideas coming from global cultural and economic exchanges. Today, many Chinese see economic targets as the highest values of their lives. This new situation is a great challenge to Christian ethics in China.

Protestant Christians in China believe that believers should be loyal, trustworthy, honest, and hardworking citizens of the secular state. This would 
give a good testimony to their faith. ${ }^{21}$ They are convinced that, living as good citizens of the society and loving their motherland, they will give a credible witness to the Gospel. This is an authentic experience of the Chinese believers, and many non-Christians testify to the reality of this attitude. And K. H. Ting gives theological support to the moral improvement of the Chinese Christians. He fights against all sorts of religious enthusiasm, e.g., on the grounds that it encourages an antinomianism that creates a dualistic separation between faith (one's relation with God) and morality (one's relation with the neighbor). Ting also opposes all forms of religious escapism.

There is the other dimension of contextualization: How can we relate the Gospel of Jesus Christ to five thousand years of Chinese cultural experience? How can we relate Christianity to the traditional Chinese ways of thinking and living?

Even here, as K. H. Ting emphasizes, the question of ethics or morality is crucially important, because traditional Chinese culture is concentrating more on morality than on religious beliefs. He says: "In China, where Confucianism has had a deep impact, the question of ethics is particularly important from a missiological point of view. Many have been brought to Christ because they were first attracted by the ethical content of the Gospel" (1989, p. 512). As we have seen, according to K. H. Ting's theological thinking, ethics is not the whole content of Christianity. Rather, it is the point of contact between Chinese tradition and the Christian faith or a "door" inviting the Chinese to enter into a fuller understanding of the Trinitarian mystery in respect to our human existence.

Ting believes that the task of relating the Christian message to traditional Chinese culture is even a greater challenge than creating a harmonious coexistence between Christians and non-Christians in modern socialist Chinese society: "The Three-Self task of Chinese Christianity is by no means completed today. The question of cultural transformation is harder than that of political belonging. When we think of the captivity and hesitation on our theological front, when we note how much old and Western stuff our life of worship and devotion still exhibits in disharmony with the Three-Self ideal ... We hope that the next thirty years of the Three-Self Movement will witness its in-depth cultural development" (1981, p. 499). ${ }^{22}$

Ting points here to an agenda for the younger theological generation in China: they must discover how to adapt the Gospel of Christ and the Trinitarian faith of the Christian church, in a profound and authentic manner, to a genuinely Chinese way of thinking and way of life. They must find a way to make Chinese Christianity less Western and more Chinese. As we saw in a quotation above, in criticizing the limits of Teilhard de Chardin's thinking, Ting implies his conviction that the Orient has something as well to offer to the whole humankind: an authentic Oriental understanding of the Christian faith might enrich the whole ecumenical family of the churches as it continues on its journey to a fuller understanding of the mystery of Christ. 
Being inspired by my study of K. H. Ting's God is Love, I would like to suggest two possible ways of further developing some kind of a connection between the traditional Chinese world view and Chinese Christian theology. The foundation for these suggestions can in fact be found in Ting's work, but they require further elaboration by Chinese theologians.

First, as we have seen, Ting feels a certain sympathy towards Process Theology, and one might link such a philosophy to elements of traditional Chinese thinking. Both the Neo-Confucians of the sixteenth and seventeenth centuries and many modern Confucians see a unity between Heaven and humanity (Tianren heyi). They promote a certain type of monism in which Heaven, the divine, and humanity exist in mutual dependence, neither existing without the other, with no sharp division between the two.

The two have some influence on each other: the perfection of Heaven, the fulfillment of its potentiality, needs human cooperation; and the authentic flowering of humanity, the development of full human potential, forges a unity with Heaven. Humans are participants in a transformative process of the cosmos. One Neo-Confucian axiom runs: "The world of ultimate reality and the world of the nature of the human person become ultimately one. This is the intrinsic authentication of the human person as it is the intrinsic humanization of reality. ${ }^{23}$ Not only process thinking but also Ting's cosmic Christology and universal Pneumatology could be linked with the Chinese concept of Tianren heyi in mutually productive conversation.

This suggestion does not at all mean that Ting's theological concepts should be considered congruent to those of Neo-Confucianism but only that there might be a point of contact between him and traditional Chinese thinking. After all, as we have shown above, in its very substance Bishop K. H. Ting's theology follows classical Trinitarian theology.

The second point of contact between Christianity and traditional Chinese culture is more obvious, a theme often mentioned as well by K. H. Ting himself, which could become an object of further elaboration by Chinese theologians in the field of Christian ethics. The above-mentioned idea of Tianren heyi is the foundation of classical Confucian ethics, which emphasizes harmony between Heaven, nature, and humanity. "The backbone of Confucian doctrines is composed of three principles: harmony and unity between humanity and Heaven, harmony and unity between descendants and ancestors, and harmony and unity between the secular and the sacred."24 In classical Confucian thinking, harmony is the supreme form of value and goodness, and harmony of the mind and the harmony of the social behavior belong together.

As we have seen, K. H. Ting often emphasizes the last of the three aspects in the above quotation: the harmony between those who have a religious faith and those who do not as well as a harmony between different kinds of faiths and believers. Harmony is certainly a religious concept, but it is even more a fundamental moral idea of the traditional Chinese culture. It is a concept that 
might become a fruitful point of contact between classical Chinese ethics and Chinese Christian ethics. Ting has made a good start by employing the idea of harmony in his theological thinking and ethics; this is a direction that deserves further attention of younger Chinese theologians.

\section{Conclusion}

After my close reading of Bishop K. H. Ting's magnum opus God is Love, I am compelled to conclude that many critics of his theology simply miss the point. Their criticism is based upon a failure to understand Ting's ecumenically-oriented Trinitarian theology. They are perhaps even reading into Ting's thought something that does not belong there. As is normal in any global theological discourse, of course, some are more "liberal" or "radical" and some more "conservative," each side being unable to come to complete agreement and even having contradictory convictions. K. H. Ting's theology cannot on the global scene be found at either extreme; rather, it must be located within the classical theological mainstream.

I understand K. H. Ting's theological methodology as a well-justified endeavor to find ways to express the core of the Christian faith in a relevant way to the people of today's China. By its emphasis on the wide scope of Trinitarian and natural theology, it offers elements for constructive dialogue between Christians and Chinese society and culture. Moreover, when I say that Ting has introduced to Chinese Christians a variety of ecumenicallyacceptable theological themes which are commonplace in the West but new in China, I do not mean that he has simply imported Western theological ideas to China. While he has learned from ecumenical theology, he has been selective in using such ideas in an independent way, and, in so doing he has been sensitive to the social and cultural context of his country and people. He has created a Chinese version of those ecumenical themes.

Committed to a Trinitarian approach and appreciating natural theology, Bishop K. H. Ting establishes some important methodological rules necessary for the development of Chinese contextual theology both in the socialpolitical sense and in the cultural sense. While he may have left the actual work of cultural contextualization or inculturation to younger generations of Chinese theologians, he has nonetheless provided in the midst of the rapid changes and developments of modern Chinese society some of the new, fresh views concerning how to relate the Gospel to social, economic, and political realities of which the church has constant need. Contextualization, considered in both of its dimensions, is an unending, ongoing process.

\section{NOTES}

1 Figures concerning the number of Christians in China are contradictory. The official Chinese figures have the tendency to underestimate the number of believers, whereas many foreign, 
especially American, organizations seem to exaggerate that number. According to Chinese scholarly sources, there are some twenty million Protestants in the registered churches and another twenty million believers in the unregistered churches. As for the Catholics, there is a similar division between the "Patriotic" and the "underground" churches, both having some five to six million members. In sum, there are, roughly speaking, some forty million Protestant and ten to twelve million Catholic believers in China. In terms of percentage, about $3 \%$ of the mainland Chinese people are Protestant and less than $1 \%$ are Catholic.

2 K. H. Ting was consecrated bishop of the Anglican diocese of Zhejiang in 1955. After the turmoil of the "Cultural Revolution" (1966-1976), Bishop Ting became the head of both the newly organized China Christian Council and the reinstituted Three-Self Patriotic Movement. In 1997 he retired from these posts but remains as their honorary president and chair. Since 1953 until the present day, K. H. Ting is the principal of the only national Protestant theological school in China, Nanjing Union Theological Seminary. He also remains the president of the Amity Foundation. On the national political scene, in 1978 Ting was named to the standing committee of the Chinese People's Political Consultative Conference and later became a vice-chairperson of that conference. He was also a member of the standing committee of the National People's Congress. Philip L. Wickeri published the first full biography of K. H. Ting in December 2007, Reconstructing Christianity in China: K. H. Ting and the Chinese Church (Maryknoll, NY: Orbis Books, 2007). Wickeri's 516-page opus is also the best analysis available on the history of Christianity in the Communist China. For a short but detailed biography of K. H. Ting, see Janice and Philip Wickeri (eds.), A Chinese Contribution to Ecumenical Theology: Selected Writings of Bishop K. H. Ting (Geneva: WCC Publications, 2002), pp. vii-xii.

3 In addition to God is Love, there are three other smaller collections of K. H. Ting's articles, essays, and speeches published in English: Raymond L. Whitehead (ed.), No Longer Strangers: Selected Writings of K. H. Ting (Maryknoll, NY: Orbis Books, 1988); Janice Wickeri (ed.), Love Never Ends: Papers by K. H. Ting (Nanjing: Yilin Press, 2000); Janice and Philip Wickeri (eds.), A Chinese Contribution to Ecumenical Theology: Selected Writings of Bishop K. H. Ting (Geneva: WCC Publications, 2002). Most of the articles included in God is Love are, in fact, taken from Love Never Ends, but without acknowledgement. Some of the essays were originally written in English, but God is Love offers no information on that.

4 The five sections are: "God's Love," "God's Love Extends to All People," "God's Love Teaches Us to Know and Serve," "Our Responses to God's Love" and "Christianity in a Socialist China."

5 The year in the brackets indicates the time when the article was originally published.

6 Augustine had already denied the possibility of a Christian state or Christian politics, but his authentic social doctrine was misunderstood in Europe in medieval times. See Miikka Ruokanen, Theology of Social Life in Augustine's De civitate Dei (Göttingen: Vandenhoeck \& Ruprecht, 1993), pp. 152-155.

7 Wickeri, Reconstructing Christianity in China, pp. 336, 348

8 The quotation is from Wickeri, Reconstructing Christianity in China, p. 360.

9 See Liu Yichun, "Why do we leave school?" www.chinahousechurch.org/chinese/ give\%20up.htm (June 25, 2003).

10 See, for instance, Li Xinyuan, "An Example of a Non-believer: Reflection on Ting's Works," Christian Life Quarterly No. 10 (June 1999). For an introduction to criticism, see also Zhu Xiaohong, "Reflections on the Reconstruction of Theological Thinking" (in Chinese), in Miikka Ruokanen and Paulos Huang (eds.), Christianity and Chinese Culture: A Sino-Nordic Conference on Chinese Contextual Theology (Beijing: China Social Sciences Press, 2004), pp. 376-390.

11 See Edmond Tang, "Theology and Context in East Asia," Studies in World Christianity Vol. 1 (1995), pp. 68-79, and "East Asia," in John Parrat (ed.), An Introduction to Third World Theologies (Cambridge: Cambridge University Press, 2004), pp. 83-84.

12 Edmond Tang, "East Asia," p. 88.

13 The first Protestant missionary, Robert Morrison came to China in 1807. In 2007 the Chinese Protestant Church celebrated the bicentennial memory of this foundational event, yet the church is still struggling with the reception of her missionary heritage. The tension between Three-Self ideology and the historical fact of the Western missionary background is still somewhat controversial in Chinese Protestant thinking. 
14 Wickeri, Reconstructing Christianity in China, pp. 48-49, 247.

15 Ibid., pp. 49, 113, 343.

16 Ibid., pp. 352.

17 Catechism of the Catholic Church (New York, NY: Doubleday, 1995), 221, 260.

18 Edmon Tang states correctly: "Given the political context of China, Ting could be easily accused of introducing the concept of cosmic Christ only as a means of building political bridges or as a corrective measure for fundamentalist Christianity, but his writings point towards a more personal spiritual vision, a foretaste of eschatological splendour." "East Asia," p. 88.

19 For an interpretation of the role of Christology and Pneumatology in K. H. Ting's theology of creation, see also Tobias Brandner, "K. H. Ting's Theological Motifs in Love Never Ends," in Wang Peng (ed.), Seeking Truth in Love (Beijing: Zongjiao wenhua chubanshi, 2005), pp. 209-212, and Lin Manhong, "A Modern Chinese Journey of Inculturation," International Review of Mission Vol. 87, No. 344 (1998), pp. 16-18.

20 For an ecumenical understanding of the relationship between Christians and nonChristians, see Miikka Ruokanen, The Catholic Doctrine of Non-Christian Religions, According to the Second Vatican Council (Leiden: E. J. Brill, 1992).

21 I often hear foreign conservative Christians criticizing Chinese Christians for their loyalty to the present socialist society. These critics fail to see that during the history of the Christian church the believers, especially in Europe, have almost always been "patriotic," loyal to their rulers.

22 Professor Chen Zemin, a long-term colleague of Bishop K. H. Ting and a faculty member of the Nanjing Union Theological Seminary since the 1950s, emphasizes the urgent need for cultural contextualization or inculturation of Chinese Protestantism: "The future of Christianity in China therefore depends on whether it is able to show in practice its dynamic transforming power in the present pluralistic, secular and changing cultural context. This transformation must be through inculturation. And inculturation requires necessary accommodation or changes in the church itself, in the presentation of the Gospel, and in its theological structure and outward forms (rituals and organizations). In other words, Christianity itself must also be transformed if it is to play the role of transmitter of Christ the transformer of culture." Chen Zemin, "Christ and Culture in China: A Sino-American Dialogue," Chinese Theological Review Vol. 8 (1993), p. 75.

23 Cheng Chungying, New Dimensions of Confucian and Neo-Confucian Philosophy (Albany, NY: State University of New York Press, 1991), p. 303. See also Du Weiming, Centrality and Commonality: An Essay on Confucian Religiousness (Albany, NY: State University of New York Press, 1989), p. 84; Paulos Huang, Confronting Confucian Understandings of the Christian Doctrine of Salvation: A Systematic Theological Analysis of the Basic Problems in the ConfucianChristian Dialogue (Helsinki: Department of Systematic Theology, University of Helsinki, 2006), pp. 117-118; Arne Redse, "By Grace Alone" in Contexts of "Self-Cultivation": An Attempt at Contextualizing the Lutheran Doctrine of Justification to Chinese Contexts as Influenced by Neo-Confucianism (Stavanger: Unpublished doctoral thesis, 2005), pp. 282-284.

24 Yao Xinzhong, An Introduction to Confucianism (Cambridge: Cambridge University Press, 2000), p. 45. See also Paulos Huang, Confronting Confucian Understandings of the Christian Doctrine of Salvation, pp. 159-160, and Arne Redse, "By Grace Alone" in Contexts of "SelfCultivation," pp. 285-287. 
Copyright of Modern Theology is the property of Blackwell Publishing Limited and its content may not be copied or emailed to multiple sites or posted to a listserv without the copyright holder's express written permission. However, users may print, download, or email articles for individual use. 